\title{
The Effect of Environmental Uncertainty on Supply Chain Agility for Small and Medium-Sized Businesses (SMBs): Empirical Evidence on Coffee Shops in Indonesia
}

\author{
Anisa Aprilia ${ }^{*} \quad$ Fitrotul Laili $\quad$ Putri Budi Setyowati \\ Kristoforus Farian Waringga \\ Afrizal Wisnu Wardana \\ Department of Socio-Economics, Faculty of Agriculture, Universitas Brawijaya, Malang 65145, Indonesia
}

\begin{abstract}
The coffee shop business that is increasingly favored by business people in Indonesia has many challenges ranging from coffee bean suppliers to consumers with diverse demographics. The purpose of this study is to investigate the effect of environmental uncertainty on supply chain agility through supply chain orientation and market orientation variables. A total of 65 coffee shops have been used as research samples which are then analyzed by PLS-SEM to determine the effect between variables. The research findings indicate that environmental uncertainty has a very significant effect on supply chain agility. Thus, business owners and / or coffee shop managers must have the ability to respond quickly to an environment where the environment is difficult to predict but the response to environmental changes can indicate the success or failure of the decision making unit in the supply chain.

Keywords: environmental uncertainty, supply chain agility, supply chain orientation, market orientation, coffee shop

DOI: $10.7176 / \mathrm{EJBM} / 12-33-08$
\end{abstract}

Publication date: November $30^{\text {th }} 2020$

\section{Introduction}

Companies can maintain competitive advantage by developing agility and innovation as their dynamic capabilities in today's global economy (Chen, 2019). In running a business, managers will be faced with uncertainties that provide more challenges to satisfy consumers in a fast time and still pay attention to quality in changing conditions, so they need to improve supply chain performance in responding to changes quickly. The skills to provide satisfaction to consumers and to deal with changes in a relatively short period of time can be called agility (Prater et al., 2001). Good performance or not in supply chain agility can determine how a business can run effectively and efficiently. If the company has capabilities in logistics, the company can achieve agility in its supply chain (Gligor \& Holcomb, 2012). Meanwhile, supply chain flexibility has emerged as an important management strategy for achieving competitive advantage and hence businesses should now pay attention to improving their supply chain management practices to be flexible and responsive to unpredictable environments and to cope with changing customer needs (Jangga et al. al., 2015).

The uncertainty of the business environment makes a producer have to choose the right way to make and implement products quickly while maintaining product quality. The uncertainty of the business environment is one of the main causes of failure in supply chains (Stratton \& Warbuton, 2003). In dealing with this situation, supply chain agility is used to solve problems with environmental uncertainty. Agility in supply chain management and end consumers has a significant impact on the sustainability and success of companies in the market (Ehtesham et al., 2019). Thus, there should be a good collaboration from upstream to downstream with a good orientation on the satisfaction of their market. According to Lin et al., (2006), to achieve competitive advantage, business people must align suppliers with customers in a way that can achieve far-reaching levels of agility.

With the increasingly dynamic times, business managers must improve their level of sensitivity to changes in market behavior. This change requires the movement of a business in the framework of production to be carried out effectively and efficiently to meet market needs so that a business actor must be ready to accept and prepare a strategy to manage business activities in order to keep up with these changes. Irfan et al., (2020) state that business people must be responsive to customers and the market. But in reality, business actors in meeting market needs must also be able to see their supply chain processes. The uncertainty of the company's environment raises two different orientations but both of them are interrelated and affect supply chain agility, namely orientation to the supply chain itself and also orientation to the market (Ehtesham, et al., 2019). In this situation, business actors must think about managing existing resources so that they can accommodate market demand. Companies that require external resources must synchronize existing resources with the market so that they need agility in their management.

The company's relationship with the market must also be maintained through various information received from end consumers. Christoper (2000) states that the main characteristic in making a supply chain agile is sensitivity to the market. Coffee shop business actors must also pay attention to market orientation. Environmental uncertainty on the market side includes consumer tastes, trends and competitors. Consumers encourage business 
actors to provide better services and products so that they have a competitive advantage. Coffee shop business actors certainly need a market as their target in producing a product. With market uncertainty, business actors must act quickly and adaptively to market behavior so as to maintain opportunities and reduce existing risks. The company must also be able to gain a competitive advantage over other companies engaged in the same field. Consumers will encourage companies to produce a product that can increase consumer satisfaction (Ehtesham et al., 2019). So that in order to meet market needs, the company must create the marketing concept desired by consumers.

Malang is one of the cities in Indonesia, which accounts for the needs of the national coffee and has many coffee shops scattered throughout the city. The phenomenon of the proliferation of coffee shops in Malang caused by the tastes of the people and the need for a place that provides the facility to support the needs of the community as examples of coffee habits attached to the community in Malang. According to Khamdani (2014), the culture of drinking coffee for certain social groups such as students or urban communities has become a symbol of identity and lifestyle. Malang society dominated by students to make coffee as a commodity that is quite popular. At first the trend of drinking coffee was just an activity to fill spare time, but nowadays the trend of drinking coffee has become a lifestyle (Ompusunggu \& Achmad, 2014). In the process, the owner of the coffee shop should be able to develop a strategy to provide the raw material supply to consumers' needs to have a competitive advantage among its competitors.

Resources are very important for the operation of a production system, so there is a need for a strong relationship between resource suppliers for producers, especially coffee shop business actors. Supply chain orientation by building chain relationships to increase the profits from the supply chain is very important for business sustainability and success (Ehtesham et al., 2019). The relationship that occurs is not only in terms of the buying and selling process, but business actors must also pay attention to the performance and improvement of the supplier's work so that the process of supply to distribution of resources can be carried out according to company needs. Good collaboration between the two will encourage the company to produce effective and efficient processes in order to meet market needs. Based on the opinion of Agarwal et al., (2007) that collaboration with suppliers not only reduces waste in the supply chain, but also increases agility, customer satisfaction, and competitiveness. An agile supply chain in response to environmental uncertainties will provide a competitive advantage over its competitors. Thus, it is hoped that this research can solve the problems experienced in the coffee shop business by providing information on how environmental uncertainty affects supply chain agility to form a mutually beneficial supply chain from upstream to downstream.

\section{Research Methods}

The development of the research model was carried out using existing research measurement units, so that this research focuses more on validating the research model with the collected data. The sampling technique used a questionnaire distributed to the owner or manager of the coffee shop in Malang City as many as 65 which were determined purposively with certain criteria. The criteria for the research sample chosen were the coffee shop owner or manager who had been operating for at least two years and had a coffee bean supplier. Of course, the number of samples is in accordance with the minimum sample requirements for PLS-SEM analysis with a statistical power of $80 \%$ (Hair et al, 2017). This research was conducted in July 2020-September 2020. While the analysis used in this research is quantitative analysis by applying the Partial Least Square Structural Equation Modelling (PLS-SEM) analysis tool on an ordinal scale, namely 1-7 (strongly disagree to strongly agree ). PLSSEM analysis is used to see how the relationship of each variable with other variables at a small sample size of data and in this study aims to see how market orientation and supply chain orientation affect supply chain agility which is predictive in coffee shops in Malang City. The PLS-SEM method is used because this method is a SEM method using a small data sample size which is commonly used to build and test a statistical model with a form of causal interaction and of course it must meet the Goodness of Fit. The model used in this study can be said to be fit when the covariance value of the matrix is the same as the covariance of the data matrix obtained.

The variable examined in this study is how environmental uncertainty is creating variable linkages between supply chain agility which is influenced by supply chain orientation and market orientation. The framework is based on theory and findings from previous research by researchers that are relevant to this research.

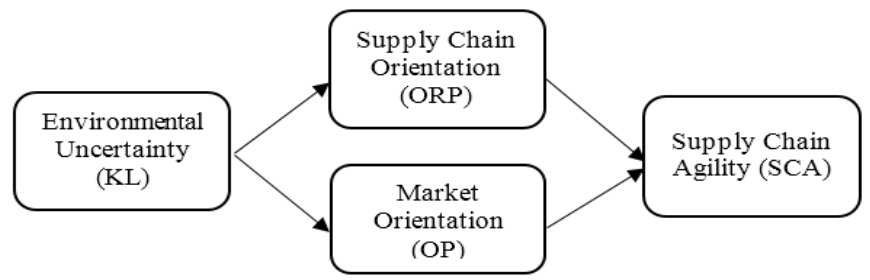

Figure 1. Research Framework 
Based on the structure of the model above, it is known that environmental uncertainty creates problems for coffee shop owners because with an uncertain environment coffee shop owners must choose between orientation towards their supply chain and orientation towards the market. These two factors are a consideration for coffee shop owners in developing their supply chains thus they can survive in the market with their competitive advantages. Supply chain orientation has a positive impact on supply chain agility because with good relationships with suppliers, store owners will easily develop their business. In addition, a good relationship between the coffee shop and the supplier will create an increase in strategic resources and the competitiveness of the coffee shop, thereby enabling increased supply chain agility. Not much different from supply chain orientation, market orientation also has a positive impact on supply chain agility. Market orientation requires coffee shops to know the needs of their consumers so that in their development coffee shops not only meet consumer needs but also provide satisfaction to their consumers. Alignment between supply chain orientation and market orientation will result in good supply chain agility for the coffee shop.

Indicators of environmental uncertainty include capacity compared to competitors, complexity of operations compared to competitors; changes in competition in the market; technology changes. Supply chain orientation indicators which consist of consistency of objectives with suppliers, priority of strengthening cooperation with supply chain actors, trust between supply chain actors, the importance of sharing information with each supply chain actor, the importance of strategy, the function of business coordination in supply chain management, the importance of the integration process within the company and the importance of the integration process outside the company. Market orientation indicators include the effects of changes in the business environment, evaluate social trends such as changes in lifestyle, coordination of production processes with suppliers, coordination about technology, and sensitivity to changes to customer needs. And supply chain agility indicators consist of response to changes in demand, cooperation with suppliers, integration of information, development of customer service levels, development of response rates, supply chain inventory (Swafford et al., 2006; Braunscheidel \& Suresh, 2009; Kim \& Chai, 2017; Rasi et al., 2019).

\section{Results and Discussions}

Data processing in this method is carried out using the PLS-SEM method which is a predictor analysis tool, so that several tests are carried out on the research model used in this study to see the level of reliability of the model used. Testing the reliability level of the model is done by taking into account Cronbach's Alpha value and Factor Loadings. The variables and indicators must have a relationship with a value above 0.7 (Hullan, 1999), this is because each latent variable used must be able to describe $50 \%$ of the diversity in each indicator. The higher the Cronbach's Alpha value and Factor Loadings or more than 0.7 , it can be said that the research model is more ideal (Sarstedt, 2011). However, if the variables and indicators have a relationship with a value below 0.4, then that variable cannot be included in the measurement model. The results of data calculation in this study can be seen in Table 1 where Cronbach's Alpha value is more than 0.7. On the other hand, the calculation results of Factor Loadings can be seen in Table 2 where each variable gets a value greater than 0.7 , but there are 2 variables that have a value less than 0.7 , namely the KL 4 and OP 5 variables. The OP 5 variable must be omitted in the research model because it has a Factor Loadings value below. 0.4. The latent variables in this study can be said as a whole to have good or reliable consistency.

Furthermore, the test is carried out by calculating the value of Composite Reliability (CR) to test internal consistency and the Average Variances Extracted (AVE) value to test the convergent validity of the research model. The results of the internal consistency test and convergent validity will have a value between 0 to 1 where the higher the value obtained or if the value obtained is close to number 1 means that the research model has internal consistency and increasingly reliable convergent validity. In measuring internal consistency, the CR value obtained must be greater than 0.6. If the CR value obtained is lower than 0.6, it can be said to be unreliable, Meanwhile, in measuring convergent validity, the AVE value obtained must be greater than 0.5 . If it is lower than 0.5 , it can be said to be invalid in convergence (Monecke and Leisch, 2012). The measurement results can be seen in Table 1 where the CR value obtained by all variables is greater than 0.6 . Thus, it can be said to be reliable and it can be seen that the AVE value obtained by all variables is greater than 0.5 so it can be said to be convergent valid.

The test is continued by measuring how much the relationship between each variable is used by looking at the value of the square root of AVE. The diagonal values in Table 3 represent the square root results of the AVE values and the results show that the KL variable has a greater correlation than the ORP, OP, and SCA variables. The ORP variable has a greater correlation than the KL an OP variable but does not have a greater correlation than the SCA variable. The OP variable has a greater correlation than the KL, ORP, and SCA variables, while the SCA variable has a greater correlation than the $\mathrm{KL}$ and $\mathrm{OP}$ variables, but does not have a greater correlation than the ORP variable.

The last test on the measurement model that is done is to test the collinearity to test whether multicollinearity occurs. This test is carried out by calculating the VIF value which must be lower than 5 (Hair et al., 2013). If the VIF value is greater than 10, there will be an indication of multicollinearity. The results showed that the variables 
KL, ORP, OP, and SCA each had VIF values of 1.419, 3.629, 2.329, and 3.892. Thus, from these results it can be seen that in the research model there is no indication of multicollinearity.

Table 1. Reliability of Measurement Items

\begin{tabular}{lccc}
\hline Variables & Cronbach's Alpha & $\begin{array}{l}\text { Average } \\
\text { Extracted (AVE) }\end{array}$ & $\begin{array}{l}\text { Variances } \\
\text { Composite } \\
\text { Coefficients }\end{array}$ \\
\hline KL & 0.756 & 0.584 & 0.847 \\
ORP & 0.935 & 0.692 & 0.947 \\
OP & 0.761 & 0.585 & 0.850 \\
SCA & 0.914 & 0.704 & 0.934 \\
\hline
\end{tabular}

Table 2. All factor loading by factor analysis

\begin{tabular}{|c|c|c|c|c|}
\hline & KL & ORP & OP & SCA \\
\hline KL1 & 0.811 & -0.067 & -0.153 & 0.168 \\
\hline KL2 & 0.869 & -0.216 & 0.133 & 0.149 \\
\hline KL3 & 0.756 & 0.259 & 0.207 & -0.479 \\
\hline KL4 & 0.592 & 0.077 & -0.249 & 0.163 \\
\hline ORP1 & 0.291 & 0.663 & 0.007 & -0.811 \\
\hline ORP2 & -0.052 & 0.835 & -0.143 & -0.285 \\
\hline ORP3 & -0.063 & 0.840 & -0.187 & -0.126 \\
\hline ORP4 & -0.205 & 0.850 & 0.106 & -0.198 \\
\hline ORP5 & -0.104 & 0.894 & 0.036 & 0.264 \\
\hline ORP6 & -0.008 & 0.875 & 0.106 & 0.372 \\
\hline ORP7 & 0.124 & 0.850 & 0.020 & 0.304 \\
\hline ORP8 & 0.089 & 0.825 & 0.048 & 0.279 \\
\hline OP1 & 0.118 & -0.194 & 0.868 & 0.090 \\
\hline $\mathrm{OP} 2$ & 0.133 & 0.425 & 0.865 & -0.565 \\
\hline OP3 & -0.104 & -0.308 & 0.849 & 0.399 \\
\hline OP4 & -0.152 & 0.085 & $\mathbf{0 . 8 3 7}$ & 0.075 \\
\hline OP5 & -0.110 & -0.567 & 0.016 & 0.637 \\
\hline SCA1 & 0.126 & -0.396 & -0.152 & 0.721 \\
\hline SCA2 & -0.009 & -0.004 & 0.001 & 0.912 \\
\hline SCA3 & -0.076 & 0.231 & 0.082 & 0.892 \\
\hline SCA4 & -0.038 & 0.349 & 0.122 & 0.882 \\
\hline SCA5 & -0.031 & -0.192 & -0.271 & 0.836 \\
\hline SCA6 & 0.057 & -0.082 & 0.200 & 0.774 \\
\hline
\end{tabular}

Table 3. Correlation Matrix: Discriminant Validity

\begin{tabular}{lllll}
\hline Variables & KL & ORP & OP & SCA \\
\hline KL & $\mathbf{0 . 7 6 4}$ & 0.480 & 0.511 & 0.481 \\
ORP & 0.480 & $\mathbf{0 . 8 3 2}$ & 0.692 & 0.840 \\
OP & 0.511 & 0.692 & $\mathbf{0 . 7 6 5}$ & 0.719 \\
SCA & 0.481 & 0.840 & 0.719 & $\mathbf{0 . 8 3 9}$ \\
\hline
\end{tabular}

The structural model used in this study is to use the PLS-SEM method to measure the closeness of the relationship and the influence that occurs between one variable and another in the structural relationship. The indicators used in this method are R2 endogenous latent variable and path coefficient $(\beta)$. The R2 value is further divided into 4 categories, namely the value $\leq 0.19$ is weak, the value $0.2-0.33$ is moderate, the value $0.34-0.67$ is substantial, and the value $\geq 0.7$ is strong (Chin, 1998). While the path coefficient value ( $\beta$ ) is divided into 3 
categories, namely $\leq 0.14$ is a weak effect, $0.15-0.34$ is a sufficient effect and a value $\geq 0.35$ is a strong influence. In Figure 2 the structural model illustrates that environmental uncertainty has a significant relationship in a substantial category and has a strong influence on supply chain orientation. This is indicated by the path coefficient value of 0.65 at a significance level of 0.01 and an R2 value of 0.42 . Environmental uncertainty has an impact on supply chain orientation, where with uncertain environmental conditions it is necessary to take action or formulate a strategy to have a positive effect and business owners are able to adapt and adapt themselves to the procurement of production raw materials according to the existing demand in the market

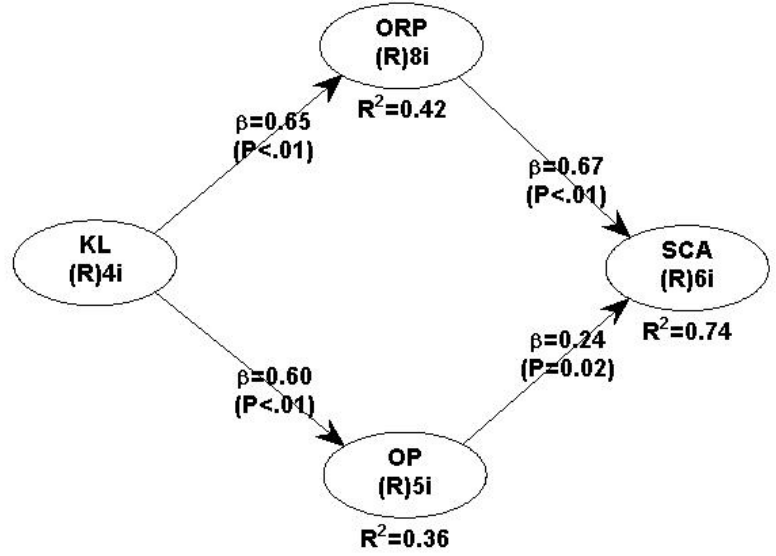

Figure 2. Research Model

Figure 2 also shows that environmental uncertainty has a significant relationship to the substantial category and has a strong influence on market orientation. This is indicated by the path coefficient value of 0.60 at a significance level of 0.01 and an R2 value of 0.36 . Changes that occur in the coffee shop business environment will continue when viewed from the increasing public interest in consuming coffee, especially in Malang City. Thus, coffee shop owners need to have a more orientation towards what consumers need and want. Environmental uncertainty encourages coffee shop owners to develop innovations in order to gain competitiveness.

Supply chain orientation has a significant relationship and a strong influence on supply chain agility as indicated by the path coefficient value of 0.67 at a significance level of 0.01 and an R2 value of 0.74 . The environmental uncertainty that occurs increases the awareness of each role in the supply chain to collaborate in facing competition. Supply chain orientation has a telling and substantial influence on how supply chain management activities are carried out. Supply chain management activities include communication, information exchange and innovation adoption so that in the end, supply chain orientation will increase supply chain agility (Esper et al., 2010).

Meanwhile, market orientation shows that it has a significant relationship and shows a fairly strong influence as indicated by the path coefficient value of 0.24 at the 0.02 significance level and the R 2 value of 0.74 . The ability of a coffee shop business owner to provide satisfaction with the needs of consumers and market desires will bring their business to excel in competition. The competitive advantage obtained will spur an increase in the volume of production and sellers in the market, in other words the company is able to adapt to the environmental uncertainties that occur. Thus, market orientation will ultimately improve supply chain agility.

The results of research on environmental uncertainty in relation to supply chain agility using PLS-SEM analysis and the variables studied were KL (environmental uncertainty), ORP (supply chain orientation), OP (market orientation), and SCA (supply chain agility), were obtained. 23 research indicators are measured to see the relationship between variables in it. Four indicators include the KL variable, 8 indicators on the ORP variable, 5 indicators on the OP variable, and 6 indicators on the SCA variable. Based on the results of the analysis, the Cronbach's Alpha value was above 0.7, which indicates that the relationship between variables in the research model has a strong relationship, but inversely if the value is below 0.7 indicates that the relationship between variables is weak. The overall results show that the relationship between variables is strong but there is 1 indicator that has a low value, namely the OP5 where the Cronbach Alpha value is 0.016 so that the OP5 indicator is not used in this research model. Based on these results, the indicators used are 22 out of 23 previously compiled. The highest Cronbach's Alpha value is obtained on the SCA2 indicator with a value of 0.912 .

The results of the convergent validity test were obtained from the AVE (Average Variances Extracted) and CR (Composite Reliability Coefficients) values of all the variables used in the study. In testing the convergent validity, the AVE value of the four variables was more than 0.5 so it could be seen that the four variables tested were known to be convergent, the variable could be said to be valid. In accordance with the statement by Monecke and Leisch (2012) that the AVE value obtained must be greater than 0.5 if it is lower than 0.5 , it can be said to be invalid in convergence. Meanwhile, the validity test using the CR value shows that all variables are classified as reliable because all variables get a value of more than 0.6 . The highest $\mathrm{CR}$ value is obtained in the ORP variable, 
which is 0.947 , this shows that the ORP variable has a higher convergent validity compared to the KL, OP, and SCA variables. The results of the collinearity test are indicated by the VIF value where when the VIF value is $\leq 5$, the data used does not contain multicollinearity. In this data, the VIF values of the ORP, OP and SCA variables were respectively $1.364,1.361$, and 1.008 so that the data was declared to have no multicollinearity.

The results obtained using PLS-SEM analysis method show that the variable environmental uncertainty has an effect on supply chain agility (SCA) because the R2 value is 0.74 in the SCA, then 0.42 on ORP and value of 0.36 on the OP. Based on the ORP path coefficient value which is influenced by the KL variable, it is 0.65 with a $\mathrm{P}$ value $<0.01$. This shows that KL has a strong influence on the ORP variable. This is in line with the opinion by Nurbaity (2017) which states that environmental uncertainty has a close relationship with the performance of a business. Environmental uncertainty affects the running of the supply chain because the company will see how the final consumer responds. Supply chain orientation greatly affects the smoothness of production and the effectiveness of making a product. So that the supply chain orientation becomes an important part of the company because it becomes one of the foundations in doing business. Of course, supply chain orientation has many chains in which there are complex risks to create value for a product. To guide and control all existing steps, supply chain orientation must be oriented towards creating value for customers and companies in the chain must create coordination so that they are able to respond to changes (Naini, et al., 2011).

Based on the OP path coefficient value which is influenced by the KL variable is 0.60 with a $\mathrm{P}$ value $<0.01$, which means that the KL variable affects the strength of the OP variable. Market orientation has a strong relationship with environmental uncertainty because the market itself changes rapidly due to customer needs. Companies that have a market-oriented tendency have a competitive advantage in responding to their customers quickly (Kumar, et al., 2011). These advantages have a positive effect on the company because even with an uncertain environment, they will still be able to predict how the needs of consumers in the future. Market orientation can increase competition between producers because the innovations that emerge will make other producers come up with their ideas to meet consumer needs. With increasing competition among producers, environmental uncertainty increases and market orientation places customers as their priority and seeks to create more value for them (Rasi, et al., 2019).

The results obtained using PLS-SEM analysis method show that the supply chain orientation variable (ORP) has a path coefficient of 0.67 at a significance level of 0.01 and an $\mathrm{R} 2$ value of 0.74 . This shows that the ORP variable has a substantial relationship with the supply chain agility (SCA) variable and has a very strong impact on the SCA variable. The ORP variable is a subject that is closely related to supply chain management and affects the strategic objectives of a business. The supply chain orientation becomes the basis for coffee shop business owners to collaborate, both with suppliers and with other parties (Mentzer et al., 2001). The results shown in this study are supported by empirical evidence from previous research conducted by (Min et al., 2007) that supply chain orientation has a strong and significant influence on supply chain management activities. Supply chain orientation becomes an operational concept that emerges and is applied from within the company which will have an impact on supply chain management activities. Supply chain management activities include stages that support the process of flowing goods into the hands of consumers. These activities start from sharing information, collaborating, and focusing on customer service. Thus, cooperation and information sharing between each actor in the supply chain creates harmonious relationships and creates better collaboration (Kim \& Chai, 2017).

The creation of good relationships and collaboration is also determined by how each actor in the supply chain has an integrated information system in it that makes it easier for the flow of information, the flow of goods / services, the flow of labor, and the flow of capital so that it can run effectively and efficiently. Therefore, it can be said that a supply chain orientation will improve the synchronization process within the company through cooperation and information rotation that leads to innovative solutions to have the power to attract markets and meet market needs through adjustments between supply and demand. Thus, this can increase the level of supply chain agility towards an increasingly positive direction in dealing with environmental uncertainty (Mentzer et al., 2001).

Meanwhile, the results of the analysis of the market orientation variable (OP) have a path coefficient of 0.24 at a significance level of 0.02 and an R2 value of 0.74 . This shows that the OP variable has a significant relationship with the SCA variable and has a strong enough influence on the SCA variable. Market orientation applied by coffee shop business actors has become a habit of business owner actions that can direct businesses to improve marketing performance. Market orientation is a more flexible strategy to create better value for consumers and better performance for business actors, especially in the uncertainty and fierce market competition (Green et al., 2006). Market orientation encourages business owners to implement business strategies that focus on improving performance in business activities. Market orientation is closely related to how coffee shop entrepreneurs meet market needs and desires by providing products and services so that they become the basis for formulating reliable strategies to become the best in the market. The better the market orientation applied by business actors, the higher the marketing performance will be. By applying market orientation too, coffee shop business actors will actually have the advantage of knowing the characteristics of their customers so that they can be used as weapons to create 
products according to consumer wants and needs (Sulaeman, 2018). Knowledge of consumer characteristics encourages coffee shop business actors to innovate, create collaboration and exchange information in order to create products according to the specifications desired by consumers so that the application of market orientation will also have an effect on increasing supply chain agility.

\section{Conclusions}

This study proves that there is a relationship between variables in this supply chain agility study. Overall supply chain agility is influenced by environmental uncertainty, with the influencing factors being supply chain orientation and market orientation. Coffee shop business actors in Malang City have a tendency to be more oriented towards supply chain compared to market orientation which has been proven from the value of the path coefficient. The average value of the path coefficient on the supply chain orientation variable is higher than the market orientation variable. Supply chain orientation is considered more important because Malang City does have a potential supply of coffee beans. One of the areas that are famous for producing coffee in Malang Regency is Dampit District with robusta coffee. Data in Statistics Indonesia (2018) shows that the coffee production of Malang Regency as a whole is 11,829 tons. Therefore it is also necessary to increase market orientation in order to increase supply chain agility at the coffee shops in Malang.

\section{Acknowledgement}

The research team would like to thank the institution of Research and Community Services of Universitas Brawijaya (LPPM-UB) as the party who provided the work in the scheme of Research Grants Beginner with the source of research funds being charged to Universitas Brawijaya. And we also express our gratitude to the owner and manager of the coffee shop who have been willing to provide information for this research.

\section{References}

Agarwal, A., Shankar, R., \& Tiwari, M. K. (2007). Modeling agility of supply chain. Industrial Marketing Management, 36(4), 443-457. doi:10.1016/j.indmarman.2005.12.004

Braunscheidel, M. J., \& Suresh, N. C. (2009). The organizational antecedents of a firm's supply chain agility for risk mitigation and response. Journal of Operations Management, 27(2), 119-140. doi:10.1016/j.jom.2008.09.006

Chen, C.-J. (2019). Developing a model for supply chain agility and innovativeness to enhance firms' competitive advantage. Management Decision, 57(7), 1511-1534. doi:10.1108/md-12-2017-1236

Chin, W. W. (1998). The partial least squares approach to structural equation modeling. Modern methods for business research, 295(2), 295-336.

Christopher, M. (2000). The Agile Supply Chain. Industrial Marketing Management, 29(1), 37-44. doi:10.1016/s0019-8501(99)00110-8

Ehtesham Rasi, R., Abbasi, R., \& Hatami, D. (2019). The Effect of Supply chain agility Based on Supplier Innovational and Environmental Uncertainty. International Journal of Supply and Operations Management Vol 6(2): 94-109.

Esper, T. L., Clifford Defee, C., \& Mentzer, J. T. (2010). A framework of supply chain orientation. The International Journal of Logistics Management, 21(2), 161-179. doi:10.1108/09574091011071906

Gligor, D. M., \& Holcomb, M. C. (2012). Understanding the role of logistics capabilities in achieving supply chain agility: a systematic literature review. Supply Chain Management: An International Journal, 17(4), 438-453. doi:10.1108/13598541211246594

Green, K. W., McGaughey, R., \& Casey, K. M. (2006). Does supply chain management strategy mediate the association between market orientation and organizational performance? Supply Chain Management: An International Journal, 11(5), 407-414. doi:10.1108/13598540610682426

Hair, J. F., Ringle, C. M., \& Sarstedt, M. (2013). Partial Least Squares Structural Equation Modeling: Rigorous Applications, Better Results and Higher Acceptance. Long Range Planning, 46(1-2), 1-12. doi:10.1016/j.lrp.2013.01.001

Hair, J. F., Tomas, G. M. H., Ringe, C. M., \& Sarstedt, M. (2017). A Primer on Partial Least Squares Structural Equation Modeling (PLS-SEM). SAGE Publications, ltd.

Irfan, M., Wang, M., \& Akhtar, N. (2019). Enabling supply chain agility through process integration and supply flexibility. Asia Pacific Journal of Marketing and Logistics, 32(2), 519-547. doi:10.1108/apjml-03-20190122

Jangga, R., Ali, N. M., Ismail, M., \& Sahari, N. (2015). Effect of Environmental Uncertainty and Supply Chain Flexibility Towards Supply Chain Innovation: An exploratory Study. Procedia Economics and Finance, 31 , 262-268. doi:10.1016/s2212-5671(15)01228-9

Khamdani, D. F. (2014). Tema Sosial yang Didialogkan Oleh Komunitas “Ngopi” di Warung Kopi Sarijan Malang. J. Pendidikan Kewarganegaraan Vol 1(1): 1770-1780 
Kim, M., \& Chai, S. (2017). The impact of supplier innovativeness, information sharing and strategic sourcing on improving supply chain agility: Global supply chain perspective. International Journal of Production Economics, 187, 42-52. doi:10.1016/j.ijpe.2017.02.007

Kumar, V., Jones, E., Venkatesan, R., \& Leone, R. P. (2011). Is Market Orientation a Source of Sustainable Competitive Advantage or Simply the Cost of Competing? Journal of Marketing, 75(1), 16-30. doi:10.1509/jmkg.75.1.16

Lin, C.-T., Chiu, H., \& Chu, P.-Y. (2006). Agility index in the supply chain. International Journal of Production Economics, 100(2), 285-299. doi:10.1016/j.ijpe.2004.11.013

Mentzer, J. T., DeWitt, W., Keebler, J. S., Min, S., Nix, N. W., Smith, C. D., \& Zacharia, Z. G. (2001). DEFINING SUPPLY CHAIN MANAGEMENT. Journal of Business Logistics, 22(2), 1-25. doi:10.1002/j.21581592.2001.tb00001.x

Min, S., Mentzer, J. T., \& Ladd, R. T. (2007). A market orientation in supply chain management. Journal of the Academy of Marketing Science, 35(4), 507-522. doi:10.1007/s11747-007-0020-x

Monecke, A., \& Leisch, F. (2012). semPLS: Structural Equation Modeling Using Partial Least Squares. Journal of Statistical Software, 48(3). doi:10.18637/jss.v048.i03

Naini, SGJ, Aliahmadi, AR, dan Jafari-Eskandari, M. (2011). Merancang sistem pengukuran kinerja campuran untuk manajemen rantai pasokan lingkungan menggunakan teori permainan evolusioner dan kartu skor seimbang: Studi kasus rantai pasokan industri otomatis. Sumberdaya, Konservasi dan Daur Ulang ing, 55(6), 593-603.

Nurbaity, F. (2017). Pengaruh Ketidakpastian Lingkungan Terhadap Kinerja Bisnis dengan Strategic Flexibility sebagai Variabel Mediasi. JURNAL MANAJEMEN DAN KEWIRAUSAHAAN, 5(1). doi:10.26905/jmdk.v5i1.1209

Ompusunggu, M. P., \& Djawahir, A. H. (2014). Gaya Hidup dan Fenomena Perilaku Konsumen pada Warung Kopi di Malang. Jurnal Aplikasi Manajemen Vol. 12(2): 188-196.

Prater, E., Biehl, M., \& Smith, M. A. (2001). International supply chain agility - Tradeoffs between flexibility and uncertainty. International Journal of Operations \& Production Management, 21(5/6), 823-839. doi:10.1108/01443570110390507

Rasi, R. E., Abbasi, R., \& Hatami, D. (2019). The effect of supply chain agility based on supplier innovation and environmental uncertainty. International Journal of Supply and Operations Management, 6(2), 94-109.

Sarstedt, M., Henseler, J., \& Ringle, C. M. (2011). Multigroup Analysis in Partial Least Squares (PLS) Path Modeling: Alternative Methods and Empirical Results. Measurement and Research Methods in International Marketing, 195-218. doi:10.1108/s1474-7979(2011)0000022012

Statistics Indonesia. (2018). Produksi Perkebunan Kopi Menurut Kabupaten/Kota di Jawa Timur Tahun 20062017. Diakses dari https://jatim.bps.go.id/statictable/2018/11/12/1390/produksi-perkebunan-kopi-menurutkabupaten-kota-di-jawa-timur-ton-2006-2017.html

Stratton, R., \& Warburton, R. D. . (2003). The strategic integration of agile and lean supply. International Journal of Production Economics, 85(2), 183-198. doi:10.1016/s0925-5273(03)00109-9

Sulaeman, M. (2018). Pengaruh Orientasi Kewirausahaan, Orientasi Pasar, Dan Inovasi Produk Terhadap Kinerja Pemasaran (Studi Pada Industri Tahu Di Sentra Industri Tahu Kota Banjar). Jurnal Ilmiah Administrasi Bisnis Dan Inovasi, 2(1). doi:10.25139/jai.v2i1.909

Swafford, P. M., Ghosh, S., \& Murthy, N. (2005). The antecedents of supply chain agility of a firm: Scale development and model testing. Journal of Operations Management, 24(2), 170-188. doi:10.1016/j.jom.2005.05.002 